\title{
Japanese government policy and the reality of the lives of the zanryü fujin
}

\section{Rowena Ward, University of Technology Sydney}

The 残留婦人 ( $z a n r y \bar{u}$ fujin, or stranded war wives ${ }^{1}$ ) are former Japanese female emigrants to Manchuria ${ }^{2}$ who, for various reasons, remained in China at the end of World War Two. They were for a long time the forgotten members of Japan's imperialist past. The reasons why the women did not undergo repatriation during the years up to $1958,{ }^{3}$ when large numbers of the former colonial emigrants returned to Japan, are varied, but in many cases, their 'Chinese' families played some part. The stories of survival by these women during the period immediately after the entry of Russia into the Pacific War on 9 August 1945, the civil war that followed, and throughout the years of the Cultural Revolution, are testament to the strength of the senzen no onna (pre-war women). At the same time, the history of how the zanry $\bar{u}$ fujin came to be in China is useful for understanding the Japanese Government's colonial policies as well as its wartime attitudes to women. The stories of survival by the zanry $\bar{u}$

\footnotetext{
${ }^{1}$ The term zanryu fujin is not an official one used by the Japanese Government. Rather, zanryu fujin is commonly used to distinguish between the women stranded in China and the zanryu koji (abandoned war children). The usual translation of the term is 'war wives' but I have chosen to include the word 'stranded' so as to reflect the reality of the women's circumstances. I acknowledge that the word fujin can have sexist connotations.

2 'Manchuria' refers to a region that was a construction of the Japanese imperialist state and is not recognised as a place name by the Chinese Government. The region is presently known as "Northeast China'.

${ }^{3}$ The official repatriation program ran from 1946 to 1948. An additional repatriation program, under the auspices of the Japanese and Chinese Red Cross, was in place from 1953 to 1958. This program was terminated following an incident in Nagasaki when a Chinese flag hanging outside an exhibition of postage stamps was pulled down. The 'Nagasaki Incident' shattered the already fragile diplomatic relations between the two countries.
}

PORTAL Journal of Multidisciplinary International Studies Vol. 3, no. 2 July 2006

ISSN: $1449-2490$

http://epress.lib.uts.edu.au/ojs/index.php/portal 
fujin also highlight the lack of understanding by the Japanese Government of the realities of the experiences of the zanry $\bar{u}$ fujin in the aftermath of the Russian invasion. Until well into the 1990s, the Japanese Government maintained policies of differentiation between them and the残留孤児 (zanryū koji-abandoned war children) on the basis that the zanry $\bar{u}$ fujin were judged to have 'freely' chosen to remain in China. As illustrated by the stories below of three women, the zanry $\bar{u}$ fujin did not necessarily initially decide to stay in China; rather, the circumstances they faced often meant they had little choice but to remain. This paper argues, then, that the stories of survival by three zanryu fujin in the period immediately after the Russian invasion are important not simply for demonstrating the reality of their lives, but for confirming that the Japanese Government's view that the zanryü fujin had 'freely' chosen to remain in China is unjustified.

\section{Political background}

It is estimated that at the time of the Russian invasion of Manchuria in 1945 there were around 2.15 million Japanese living in the region. By this time, many of the male settlers had been conscripted and therefore a large proportion of the civilian Japanese population in the country were women, children and the elderly. It was estimated that when the last repatriation boat left China in 1958, more than 10,000 Japanese women and children remained behind (Ōba and Hashimoto 1986, 66). It was not until 1972, when diplomatic relations between the People's Republic of China (PRC) and Japan were established, that many of these people had the opportunity to migrate/return to or visit Japan.

With the establishment of diplomatic relations, the Japanese Government was forced to develop policies on how to manage the migration of the Japanese whilst simultaneously maintaining an immigration policy that restricted the inflow of people to those with specific skills. An added complication was that many of the Japanese in China had lost 
their Japanese citizenship in 1959, when a new law reduced the period before which a missing person could be declared dead. ${ }^{4}$

In developing its policy on assistance to the Japanese wishing to migrate to Japan, the Japanese Government chose to use age to differentiate between people who would be entitled to government assistance and those who would not. The decision was justified on the basis that people who had 'freely' chosen to remain in China should not be entitled to assistance since they had made a decision not to return to Japan. In contrast, it was thought that those who did not make the decision to stay of their own free will should be allowed to receive assistance. The age of thirteen was set as the dividing line between those who could receive assistance and those who could not. People who were 13 and over at the time of the Russian invasion and who were registered in a mainland family register ${ }^{5}$ were deemed to have 'freely' chosen to remain in China and therefore were eligible to receive only very limited levels of government assistance. Restrictions on the number of visits they could make to Japan were also imposed. When asked on what basis the government had decided on 13 years, a Japanese Government official replied, 'That the government needed to draw a line somewhere and the age of 13 seemed as good as any' (Ogawa 1995, 36). People who had not turned 13 years old at the time of the invasion — popularly known as the zanry $\bar{u}$ koji-were provided with assistance in their self-identification process and locating their families. ${ }^{6}$

Importantly, gender was not used as a means of differentiation. Rather, because no males were found to be in a similar predicament to the women, the word fujin (meaning 'wife/wives') came into general use. The lack of males in a similar situation can be attributed to the fact that any males found by the Russians were either killed or taken to labour camps in Siberia.

\footnotetext{
${ }^{4}$ As a result of this change in law, the number of officially listed non-repatriated civilians fell from 77,000 to 31,000 (quoted in Trefalt 2003, Japanese Army Stragglers and Memories of the War in Japan 1950-1975, 32).

${ }^{5}$ Registration of births, deaths and marriages of Japanese citizens must be registered in family registers located in the local administrative offices.

${ }^{6}$ Due to their young age and / or the circumstances surrounding their separation from their families, many zanryu koji could neither remember anything nor present concrete evidence that could be used to identify their Japanese names or family details.
} 


\section{Policy}

Initially, the Japanese government policies on the permanent migration of all 中国残留 邦人 (chūgoku zanryū hōjin - Japanese citizens abandoned in China) required that returnees had a personal guarantor in Japan who was willing to cover resettlement expenses. Finding a guarantor was often difficult, and some zanryū hōjin were unable to migrate to Japan because they could not find anyone willing to act as a guarantor. This policy covered all zanryū höjin including those who still held Japanese citizenship. In 1989, the need for a guarantor was replaced by that of a supporter or someone who was not required to provide the same level of financial responsibility as a guarantor. This change in policy made it easier for the zanryu hōjin and their families to migrate to Japan.

Until 1991, short-term visits by the zanryū fujin had to be partially self-funded as the Japanese Government only provided the return airfare. Since 1991, the Government has also provided accommodation expenses. Short-term visits by the zanryü fujin were also limited to one every 10 years, with a cap of two visits by each zanryu fujin. In 1993, the government increased the number of visits allowed by an individual zanry $\bar{u}$ fujin to once every five years and, in 1995, agreed to fund annual visits to Japan. By contrast, from the late 1970s the Japanese Government provided administrative assistance to $z a n r y \bar{u}$ koji searching for their biological families. In 1981, it also introduced a program whereby zanryū koji could travel to Japan on fully funded short-term visits for the purpose of looking for their biological families ${ }^{7}$.

\section{How did Zanryū Fujin come to be in Manchuria?}

Encouraging the emigration of Japanese citizens to Manchukuo formed one part of the Japanese Government's policy for the development of the country. Many of the Japanese living in the area had migrated with their families as members of pioneer groups, which were formed as part of the Government's 1936 plan to have the Japanese

\footnotetext{
${ }^{7}$ Due to a fall in the proportion of zanryu $\bar{u}$ koji being identified through this program, a more restricted program was introduced in 2000.
} 
population make up 10 per cent of the population of Manchuria within 20 years. Around 50 per cent of pioneer groups were sent to areas close to the Russian border (Kinoshita 2003, 23). That is, they were effectively used as human shields. Many of the women who became stranded in China had migrated with their husbands or families as members of pioneer groups, or had been members of women's volunteer groups. The rationale behind the formation of the latter groups, sometimes known as hanayome (bride groups), was to provide the overwhelmingly male settler population with brides. In the aftermath of the Russian entry into the war, large numbers of Japanese people died of starvation, in mass suicides, or in attacks by Russians or local Chinese. Others underwent repatriation. An unknown number of women who survived the initial invasion decided to marry a local man for safety for themselves and/or their families. Some of these women were married to Japanese men who had been conscripted but, without any means of contact, they did not know whether their husbands were dead or alive. Others had never married, whilst yet more were separated from their families or the people they were travelling with in the chaos of trying to escape.

The following narratives outline the lives of three women in the period immediately after the Russian invasion. Each of these women returned to live in Japan in the 1970s and 1980s. Consequently their stories are not necessarily representative of all zanry $\bar{u}$ fujin; particularly given that many remain in China. Nonetheless, these women's stories were chosen to represent women who had migrated as members of pioneer groups as well as members of volunteer groups. The women also came from different parts of Japan and were of different ages at the time of their migration to Manchuria.

\section{Kurihara Sadako’s story ${ }^{8}$ (栗原貞子)}

Sadako migrated to Manchuria from Okayama Prefecture in 1944 as a member of a women's volunteer group. ${ }^{9}$ She was 17 years old. Sadako agreed to go to Manchuria when asked to do so by her school principal out of a sense of duty to the Emperor. Her decision to go to Manchuria was made despite opposition from her family. Sadako had

\footnotetext{
${ }^{8}$ This biography is an abridged translation of Kurihara's biography in Ōba and Hashimoto 1986, 58-76. The original is in the third person.

${ }^{9}$ Okayama Prefecture faces the Inland Sea. It is located between the cities of Kobe and Hiroshima.
} 
every intention of returning to Japan after the eight-month enlistment period.

Nevertheless, the underlying assumption behind the women's groups was that the members would marry settlers. Thus when she received a marriage proposal from a man from Miyagi Prefecture, Sadako was given no option but to accept, despite repeatedly stating that she had promised her mother that she would return to Japan. Sadako was married in a mass wedding ceremony in the grounds of the Boli (勃利) administrative offices in late 1944. She had been in Manchuria just six months. The couple went to live in Kokuryūkō Province (黒龍江省) where they built a house. Her husband was conscripted in July 1945 and less than a month later, with the Russians approaching and six months pregnant with her first child, Sadako was forced to flee. She believed that she would soon return. Together with about 20 other people, she walked for about four days to Boli where they boarded a freight train headed for Mudanjiang (牡丹江). Shortly afterwards however, the train was attacked and everyone on board headed for the hills. Concerned that with her bulging stomach she would be easily seen, Sadako hid out during the day and walked at night. Captured by a Chinese person the next morning she was taken to what had previously been a Japanese camp but that now served as a barracks used by the Nationalists. Sadako stayed there for about a month before she was put on a horse-drawn carriage bound for Boli. However, the carriage was attacked by the Russian Army before it reached its destination and Sadako was taken prisoner. Not long afterward, she and three others escaped from the barracks where they were being held. Around October, she found herself at the house of a landowner where she helped out on the farm in exchange for food. Without any means to contact the Japanese mainland, Sadako was unsure as to whether her husband was dead or alive. One day, a Korean living nearby asked what she intended to do and suggested that she get married for her own sake as well as that of her unborn child. Thinking that she needed to at least ensure that her unborn child survived, she agreed to marry a Chinese farmer. Ten days later she gave birth to a son whose birth was met with much jubilation by her husband and his family. Unable to breastfeed him, she asked her husband to give the child away; he refused and daily went to fetch milk for the child. Sadako learnt Chinese and became a member of the family and the community. She had a further five children to her husband who encouraged her to visit 
Japan when diplomatic relations were established. In 1975, Sadako and one of her daughters visited Japan. Accompanied by two daughters, Sadako migrated permanently in 1980. Sadly, her husband had passed away in the meantime.

In summary, circumstances prevented Sadako from returning to Japan during the years when repatriation was an option. In the initial months after the Russian invasion she tried a number of times to escape the region but was unable to do so. Without any means to contact Japan, she decided to marry a Chinese man in order to provide security for her unborn child and herself. Once married, she became focused on her family. To assume that Sadako freely chose to remain in China does not do justice to the circumstances that led to her remaining in China.

\section{Yamada Tami’s Story ${ }^{10}$ (山田タミ)}

Yamada Tami was born in Nagano Prefecture in $1927 .{ }^{11}$ Her father migrated to Manchuria as a member of the Yomikaki pioneer group (読書開拓団) in the spring of 1939. ${ }^{12}$ The rest of the family followed in the summer of the same year. Tami was 12 years old. On 9 August 1945, a telephone call to say that all men between the ages of 18 and 45 years were to be conscripted, effective immediately, was received at the local village office. With this call, the villagers became aware that the Russians had entered the war. To the background of 'Banzai', the men were farewelled the next day. Tami's father, eldest brother and second-eldest brother were conscripted at the time. Tami said that she began to feel some concern about the war situation when she saw smiles on the faces of the Chinese onlookers as the Japanese men departed for the war.

On the evening of 11 August, a telephone call from the police told Tami's family that everyone was to evacuate to Mudanjiang. Tami and her mother collected some valuables and, with her younger sister on her back, Tami and her family set off for

\footnotetext{
${ }^{10}$ Abridged translation of Tami's story in Hayashi 1986, 12-14, 25-53. Details about Tami's life both in China and Japan that are not directly relevant to this paper have not been translated.

${ }^{11}$ Almost 12 per cent of the Japanese emigrants to Manchuria were from Nagano Prefecture. Figures from Young (1999, 329-30).

12 Pioneer Groups were often named after the districts in Japan from where the members originated. Yomikaki Village merged with two other villages in 1961 and is now part of Nagiso Town.
} 
Mantetsu Yanjia (満鉄 閻家) Station. ${ }^{13}$ About 3,000 people gathered on the platform waiting for the order to board a train that was standing at the platform. After some time, Tami suggested to a person near her that they should get on but when they made a move to do so, someone yelled 'Hikokumin! (un-Japanese!) Running away is unJapanese' (Hayashi 1986, 26) at them and they decided not board. The train left the station shortly afterwards with nobody on board. Tami and her family returned to their home, which had already been taken over by a local family.

On 14 August a second evacuation order was received and the family gathered at the local administration office once more. Around 16 August everyone who had gathered at the administration office headed into the mountains where they became lost and ended up walking in circles. Her mother wanted to commit suicide, ${ }^{14}$ but Tami encouraged her to keep going; with her five-year-old sister on her back and her younger sister carrying their one-year-old sister, the family kept walking. Her mother was unable to feed the baby so Tami chewed any food as much as possible and fed it to the baby to keep her alive. In crossing one river, the family's clothes got wet and since all other clothes had been lost in the turmoil of an attack, the family was forced to walk naked. Tami found some clothes beside the road, which she made the family wear. Since she was short, Tami was able to wear boy's clothes. This proved fortuitous as she was not recognised as a girl and therefore was not raped by the Russians, as many of the other females were. Upon leaving the mountains, the group was attacked from the air by the Russians. Sometime in early September, Tami was captured by the Russians and put into a camp. At night the Russian soldiers raped the women and shot people indiscriminately. The camp became the venue for the buying and selling of women and children to local Chinese families. Due to the lack of food Tami decided, against her mother's wishes, to become the wife of a local man on the proviso that her family could live with her. In this way, Tami became the wife of a second son from a very poor family. Her husband (in Australian idiom a ratbag) regularly beat and raped Tami, who gave birth to nine children. Although the villagers were initially quite antagonistic towards Tami, she

\footnotetext{
${ }^{13}$ Mantetsu is the common abbreviation of Manchukuo Tetsudō or Manchuria National Railways.

${ }^{14}$ An unknown number of people committed suicide, often by drinking cyanide, rather than be caught by the Russians or Chinese.
} 
worked hard and helped them with various chores; as a result they began to support and protect her. Nevertheless, as a Japanese person, her situation was vulnerable. Once when her husband was taken in for questioning, Tami asked for a divorce but the authorities refused. ${ }^{15}$ Tami believes this denial arose because she was Japanese and had no registration papers; therefore the authorities did not know what to do with her, and chose instead to ignore her request. At the time, she should have been eligible to receive a divorce.

Not long after she married, her mother, sister and younger brother died. Her second eldest brother, who had been conscripted in August 1945 and was subsequently captured by the Russians, managed to escape and find his way to where Tami was living. He got a job in the forestry industry and lived nearby. In 1953, he decided to take up the opportunity for repatriation and returned to Japan, taking one younger brother with him. Tami's younger sister was very ill at the time and could not go with them. She died shortly afterwards. At the time that her brother returned to Japan, Tami decided to remain in China for the sake of her own children. Once in Japan, her brother sent her a letter to say that her father and eldest brother had died. This was the first time that she had heard any news of them since they had been conscripted in August 1945.

In summation, Tami decided to marry a Chinese man in order to keep her family together. Later, she chose to remain in China for the sake of her children whom she knew she would not see again if she returned to $\operatorname{Japan}^{16}$. It is hard to justify either of these decisions as ones freely made.

\section{Ikeda Hiroko's story ${ }^{17}$ (池田広子)}

Ikeda Hiroko was born in 1930 in Kagoshima Prefecture, on the island of Kyūshū, the southernmost island of Japan's four main islands. She migrated to Manchuria in the summer of 1944 with the other eight members of her family as part of the Ikantsū

\footnotetext{
${ }^{15}$ One of the reforms instituted by the Communist government was the freedom to request a divorce.

${ }^{16}$ Under Japan's patrilineal citizenship laws at the time, Tami's children, should they have been able to accompany her, would not have been entitled to Japanese citizenship because their father was Chinese.

${ }^{17}$ Abridged translation from Hayashi (1986, 103-112).
} 
pioneer group. On 9 August, 1945, the people living in the village headed into the mountains, from where they moved to Harbin on the 15 August. After some twenty days of walking, the guard accompanying them said that it was too dangerous for them to go any further and ordered everyone back. The return journey was more difficult, and the group was often attacked by locals. Just before they made it back to their original departure point, a number of Russians looking for women appeared. Hiroko escaped into a field of millet and waited until morning. The group reassembled the next day and continued their journey. When they drew close to their village, they discovered that it had become a refuge for other Japanese groups and so they did not return to their homes. Instead they slept in the fields and kept warm by digging a hole in the ground. People stole guns, food and cooking utensils from a former Japanese army warehouse located nearby. Once when Hiroko and a few others went there to steal some food, all but except Hiroko were caught by the Russians who killed and/or raped the women.

In January 1946, at the age of 15, Hiroko sold herself to a man who became her fatherin-law in return for two cobs of corn. Shortly afterward, her second youngest sister and only surviving brother died. Her parents also died. Hiroko's husband was 23 years old and although a kind man, he was physically very weak as a result of having done hard labour in a Japanese aircraft factory during the war. Within some five months, Hiroko could converse in Chinese. Nevertheless, she felt lonely: she had sold herself to save her family but nonetheless, they had died.

The village where she lived became the scene of intense fighting between the Communists and government forces. In the summer of 1946, the Communists took control of the village and Hiroko and her husband were forced to flee to a village further into the mountains. When they returned to the village in 1947, they found their house had been destroyed. Hiroko's father-in-law and her husband were captured and put in prison. Her husband was badly beaten and as a result was unable to work for sometime thereafter. Hiroko was also taken in for questioning and was repeatedly interrogated about the location of weapons and details of the family's finances. Hiroko continuously answered that she did not know anything but was sentenced to death. At 
the time she had a three-month-old daughter. Upon hearing the verdict of death, her sister started crying. Speaking in Japanese, Hiroko told her sister not to cry as she had lived more than enough for her seventeen years. On hearing her speak Japanese, the cadres started calling her a Japanese imperialist. When asked whether she had a last request, Hiroko asked that they spare her daughter since she was part-Chinese. A leader who heard the verdict stated that 'Japanese imperialism is wrong but since she was a member of a civilian pioneer group, she is effectively a worker and therefore should live' (Hayashi 1986, 109). As a result, the verdict was overturned. The leader effectively saved Hiroko's life. For about a year after his beating, Hiroko's husband was unable to work, so Hiroko begged for food to support the family. In 1948, the family started to receive food from the interim government and, with the establishment of the PRC in 1949, her husband became a free farmer. Hiroko worked at home and had three children.

In summary, Hiroko made the choice to marry a Chinese man for the sake of her family. Although many of those family members later died, their deaths did not free Hiroko from her initial decision to marry for their sake. In effect, Hiroko was never in the position whereby she could choose between staying in China and returning to Japan.

\section{Conclusion}

In short, the stories of these women indicate that the Japanese Government's initial assumption that the zanryu fujin 'freely' chose to remain in China is difficult to justify. It is true that some women may have chosen to remain in China but an overwhelming number had few choices other than to marry local men if they wished to survive. Once married, many of the women had children and became focused on their 'Chinese' families whom they could not take with them if they had decided to return to Japan. At the same time, the women were forced to deny their 'Japanese-ness' and Japanese histories in order to protect themselves and their families. The geographical remoteness of the villages where the women lived also meant that they had few opportunities to avail themselves for repatriation. Added to this, the civil war that continued until 1949 meant that many zanryu fujin would have few if any opportunities to transit to places 
where they could organise repatriation. Finally, although the Japanese Government belatedly removed many of the barriers that prevented the zanry $\bar{u}$ fujin from visiting and / or returning to Japan after the establishment of diplomatic relations with China, it should not be forgotten that many may have 'chosen' to return earlier if diplomatic relations had been better and if the Japanese Government's initial policies governing their return had not been based on an arbitrary decision to differentiate between citizens whom it judged to have 'freely' chosen to remain in China and those who had not. This decision effectively made the zanryū fujin 'victims' of Japanese Government policy twice: first, when sent to Manchuria, and again when prevented from returning to or visiting Japan in the early years after diplomatic relations were restored.

\section{Reference list}

Hayashi, Iku 1986, Manshū: sono maboroshi no kuni yue ni, Chikuma Bunsho, Tokyo. Kinoshita, Takao 2003, Chūgoku zanryū koji mondai no ima o kangaeru, Chōeisha, Tokyo.

Mori, Takemoro 2003, 'Colonies and Countryside in Wartime Japan', in Farmers and Village life in Twentieth-Century Japan, Waswo Ann and Nishida Yoshiaki (eds), Routledge, New York.

Ōba, Kaori and Susumu Hashimoto (eds) 1986, Haha to ko de miru: Chūgoku zanryū nihon koji, Kusanone Shuppankai, Tokyo.

Ogawa, Tsuneko 1995, Sokoku yo, "Chūgoku zanryū fujin” no hanseiki, Iwanami Shinsho, Tokyo.

Trefalt, Beatrice 2003, Japanese Army Stragglers and Memories of the War in Japan 1950-1975, Routledge, London.

Young, Louise 1999, Japan's Total Empire: Manchuria and the Culture of Wartime Imperialism, University of California Press, Berkeley. 